\title{
The use of external perceived injustices by AMCU in the South African Platinum Mining Industry
}

\author{
by Prof Albert Wöcke* and Jana Marais
}

\begin{abstract}
Social movement theories applied to industrial relations are insufficient to explain recruitment and collective action focused on perceived injustices that are external to the workplace and that an employer has a limited ability to influence. The South African platinum mining industry has been characterised by increased collective action and the emergence of a new independent union at the expense of the incumbent union. The new union has mobilised primarily on external injustices that employers cannot directly influence. 299 Union members were interviewed of rival unions to examine the effect of using external perceived injustices as the main driver for collective action in the platinum mining industry in 2012//2013. The findings extend prior research on social movement theory and industrial relations and discuss the implications for unions allied to government and employers.
\end{abstract}

Key words: trade unions, social movement theory, collective action, platinum mining, strikes

\section{Introduction}

Prior work on union mobilisation tends to focus mainly on the role of the employer as the source of perceived injustice, and not on the role of the union or external factors as the potential source of injustice (Kelloway, Francis, Catano \& Teed 2007; Kelly 1998). Johnson and Jarley (2004), building on the work of Kelly (1998), recommended that the link between union participation and member justice perceptions outside the workplace should be examined but little has been done in this area. While proponents of social movement unionism argue that issues around global fairness, general income inequality and societal discrimination can mobilise people to join unions and engage in collective action, not much work has been done to comprehensively link these perceptions to union participation in the workplace (Johnson \& Jarley 2004). Van Stekelenburg and Klandermans (2013) call for more research on the impact of the socio-political context on the intention to engage in collective action. The decision to engage in collective action, it is argued, does not occur in a social vacuum; on the contrary collective action occurs within an appropriate context. Prior research on collective action in industrial relations has lacked a real-life economic, social and political context. The study was carried out within the context of a relatively deprived community in the North West Province of South Africa.

\footnotetext{
* Prof Albert Wöcke is a member of the Gordon Institute of Business Science, University of Pretoria Ms Jana Marais is a member of the Gordon Institute of Business Science, University of Pretoria.
} 
The use of SM theory in IR studies is largely attributed to Kelly's work (1998), which sees the mobilisation of workers taking place through the development of a sense of injustice at work and the identification of a collective interest, followed by collective action in response to the perceived injustices. Gahan and Pekarek (2013) show that the use of SM theory in IR is largely underdeveloped as unions are significantly more complex than social movements and have a bureaucratic function and institutionalising impact over time. However, Gahan and Pakarek (2013) argue that the revitalisation of unions may require them to engage more closely in SM strategies and approaches. Gahan and Pekarek (2013) call for the application and extension of SM theory to inform trade union research into understanding how unions mobilise and sustain collective action.

Prior work on the social psychology of protest also suggests that efficacy plays a role in collective action, in that people are more likely to engage in collective action when they perceive that there is a good chance that they will be successful in having their grievances addressed (Van Stekelenburg \& Klandermans, 2013). When this theory is examined in an IR context, strike action for perceived injustices outside the workplace would not be expected to serve as sufficient motivation for collective action, particularly when the target for the collective action is an employer that lacks the ability to directly influence the perceived injustice. However, this was not the case in the South African platinum industry and the dominant union, AMCU, successfully recruited and mobilised around social and workplace issues.

\section{Background to the South African platinum mining industry}

The South African platinum mining industry is largely situated around Rustenburg in North West. This area has seen a significant influx of people trying to find work on the mines and smelters in the area, leading to significant backlogs in housing, sanitation, water and electricity provisioning by government. About $42 \%$ of Rustenburg's population live in shanty towns without adequate service delivery, compared with an average of $15 \%$ for the rest of South Africa (Mathews 2013).

The NUM was the dominant union in most of the platinum mines up to 2012, when larger numbers of workers left NUM to join a small, unrecognised union, AMCU, and began to engage in a series of unprotected strikes. The wildcat strikes after 2012 led to additional wage increases outside the normal bargaining timelines, and tough and protracted negotiations between the mining houses and $\mathrm{AMCU}$. One of the most shocking incidents was the shooting of $38 \mathrm{AMCU}$-aligned workers by the police at the Marikana mine in August 2012.

The South African mining industry has developed in a manner contrary to the global trend of declining union influence and 2014 saw the conclusion of a five-month strike that was led by a relatively new and unknown union, the Association of Mineworkers and Construction Union (AMCU). AMCU became the dominant union in the platinum industry, supplanting the National Union of Mineworkers of South Africa (NUM) in a relatively short space of time. This has been accompanied by collective action that is largely unprotected and is associated with violent conflict, the most prominent manifestation of which was the shooting of 38 miners at Marikana in August 2012 when AMCU members confronted police who were attempting to break up an illegal gathering. AMCU was formed by disgruntled NUM members and its growth has been to the result of mine workers resigning from NUM to join AMCU. AMCU's growth has also corresponded to increasingly militant collective action and it has mobilised around both workplace and external issues. This is in contrast to NUM, which has been mobilised primarily around workplace issues and is in an alliance with the ruling ANC government. 
During the 2012 strikes in the Rustenburg platinum belt, AMCU followed a strategy of mobilising both the workers at the mines in the Rustenburg region and the residents of the shack settlement communities in the area (Malala 2012). In these communities, which became off-limits to the police, the strike became a battle against the government, rather than just a union matter and was actively supported by NGOs, church groups and political parties opposed to the ANC (Malala 2012). By the end of 2013, AMCU was the dominant union in the platinum mining industry in South Africa.

AMCU's rise in the platinum sector could be attributed in part to its ability to identify and frame issues that extended beyond the workplace (Seccombe 2012). There is a close connection between the communities where the Rustenburg mine workers live and their workplaces, and AMCU linked workplace issues, such as wage demands, to the living conditions of the mine workers (AI Jazeera 2012). AMCU's growth has also been fuelled by disaffection among members with NUM union leaders, who have been accused of being out of touch with workers' needs and too closely aligned to government and corporate interests (Seccombe 2012; Gordon, Roberts \& Struwig 2013; Zibi 2014). Many miners felt that the union's leadership has lost touch with their concerns, which include broader external issues such as community services (Peyper 2012; Buhlungu 2013; Zibi 2014).

\section{Literature review}

Kelloway et al (2007) argue that there is a considerable overlap between the reasons why people join unions and why they participate in social movements. Participating in a union, voting for a union in a certification drive, strike voting and accepting a leadership position in a union can be seen as acts of social protest (Kelloway et al 2007). Klanderman's $(1997 ; 2002)$ model of participation in protest identified three factors influencing an individual's decision to participate: a perceived injustice needs to be present, the individual must be able to identify with the group affected by this injustice, and the individual must perceive that participation in the activities of this group will be effective in addressing the injustice.

\section{Collective action and perceptions of injustice}

There are various theories to explain why grievances develop; two of the most prominent of these are relative deprivation theory and social justice theory (Van Stekelenburg \& Klandermans 2013). Feelings of relative deprivation result when individuals compare their own situation with a standard, for example their past, someone else's situation, or a cognitive standard such as equity or justice, and perceive that they are not receiving what they deserve (Van Stekelenburg \& Klandermans 2013). Individuals may also experience relative deprivation at group level, for example when the group's experience becomes relevant to one's own experience. Individuals who experience both personal deprivation and group deprivation are the most strongly motivated to participate in protest action (Van Stekelenburg \& Klandermans 2013). The application of this theory is clear in the context of internal, or workplace-related, injustices, but is less clear when trade unions mobilise around injustices external to the workplace where it is unlikely that the individual employer is able to influence the injustice and the workers are part of a larger social group. In such a context the union could be expected to be part of a broader social coalition aimed at influencing government. This was not the case in the platinum industry and AMCU successfully mobilised and sustained collective action without directly engaging with the South African government. 
Social justice theory has been used to study the relationship between grievances and protest. Social justice literature distinguishes between two forms of injustice: distributive injustice, which is similar to relative deprivation theory as it is measured by the perceived fairness of outcomes or allocation of awards, and procedural injustice, which is measured by the perceived fairness of the process by which the outcomes are determined (Kelloway et al 2007; Van Stekelenburg \& Klandermans 2013). According to Kelly (1998), injustice serves as the central organising principle for mobilising workers, and therefore provides a potentially powerful construct for examining union participation and industrial relations processes. What is crucial is that workers attribute the injustice to a party responsible for causing the problem, alleviating it, or both (Johnson \& Jarley 2004). Workplace injustice stems directly from managerial inaction, and is described as a type of dissatisfaction that arises because the actions of management lack moral defensibility (Johnson \& Jarley 2004).

\section{Instrumentality and loyalty as predictors of collective action}

Additional predictors of collective action are union instrumentality and loyalty to the union. Kelloway et al (2007) found intent to participate was predicted most significantly by perceptions of distributive injustice and perceived instrumentality, and marginally by perceptions of both procedural injustice and loyalty. However these may be different for unions whose areas of operation straddle both workplace and social causes, as is the case with AMCU but not with NUM. Union instrumentality is based on individual perceptions of the effectiveness of protest participation. The more effective an individual believes protest participation to be, the more likely he or she is to participate (Van Stekelenburg \& Klandermans 2013). Perceptions of union instrumentality have been a consistent predictor of members' participation in the union (Kelloway et al 2007). Union instrumentality is a reflection of union members' belief that their union plays a role in improving their working conditions and conditions of service and plays an important role in the decision to join a union (Goslinga \& Sverke 2003:295). A precondition for instrumentality is an effective movement that is able to mobilise substantial support and enforce some desired changes (Klandermans 2004). The expected instrumental value of collective action is determined by the individual's subjective estimate of cost and benefits and the expected success of the collective action (Feather 1992 in Giguère \& Lalonde 2010). Participants also perceive instrumental value in collective actions when they conclude that while collective actions produce few immediate rewards (for example strike action that does not lead to an improved wage offer from employers), they have long-term benefits (Giguère \& Lalonde 2010).

Several scholars (e.g. Barling, Fullagar, Kelloway \& McElvie 1992; Metochi 2002) have found a strong link between union loyalty and willingness to strike. The more loyal members are to the union, the more willing they will be to become involved in the union and to participate in trade union activities. In order to increase the commitment to the union, members should be involved in decision-making processes, while certain selective incentives may help to increase commitment (Klandermans 2004). This is in line with the seminal work of Gordon, Philpot, Burt, Thompson and Spiller (1980), where it was shown that commitment to the union is a strong predictor of an individual's propensity to strike. Gordon et al (1980) define union commitment as a member's psychological attachment to his or her union based on identification with the union's goals and values and an appreciation of the services that it provides. There appears to be a positive correlation between members' perceived union support and union commitment, the different types of union participation and the intention to remain a member of the union (Goslinga \& Sverke 2003). However, this group of theories is 
predicated on influencing the employer to change the conditions of the workers. This theory would hold for unions that focus on workplace-related issues, but its applicability is less clear when unions mobilise members around issues external to the workplace issues that employers have less ability to influence.

The study aimed to assess whether there are significant differences in the perceptions of injustice (internal and external), union loyalty and union instrumentality between members of rival unions NUM and AMCU and whether these would provide different predictors of participation in collective action. NUM is mainly focused on workplace-related matters, whereas AMCU has recruited and mobilised around broader societal injustices.

\section{Methodology}

A structured questionnaire was used to gather data from union members in the platinum belt in 2013. The questionnaire was based on the model developed by Kelloway et al (2007) to predict participation in collective action and introduced an additional source of perceived injustice, namely socio-economic conditions (external injustice). Union loyalty and instrumentality were also measured, as these are known indicators of intention to engage in collective action. The questionnaire consisted of a section designed to collect demographic data and six sections addressing the constructs. The answers were evaluated according to a five-point Likert-type scale (rated from 1 to 5 ) to assess at which level each construct was experienced by union members.

The first five questions on procedural justice were designed to address perceptions around justice in the workplace, and the last four questions addressed perceptions around justice in respect of external factors that influence socio-economic conditions. Similarly, the first four questions under distributive justice were designed to address perceptions in the workplace, while the last four addressed perceptions around external factors that influence socio-economic conditions. Respondents were then asked questions to test union instrumentality, loyalty and commitment and their intention to participate in collective action.

\section{Sample}

Data were collected from August to October 2013, when the labour relations climate was particularly tense. Owing to on-going labour instability in Rustenburg, workers were surveyed at home or in their communities. Five mining communities in the Rustenburg area were targeted: Marikana, Wonderkop, Nkaneng, Mooinooi and Phokeng. Because of ongoing violence and intimidation in the area, a convenience sampling method was used to access respondents. The sample included 352 respondents. After eliminating respondents who did not belong to a union, or who did not answer most of the questions, 299 responses were included in the data set. The survey initially targeted 100 NUM members and 100 AMCU members. Of the respondents included in the statistical analysis, 90 belonged to NUM, 172 to AMCU and 37 to a third union, UASA. Although UASA members were not targeted, the number of respondents from UASA was quite surprising, and seemed to bear out anecdotal evidence that suggests that UASA has been a beneficiary of the violent rivalry between AMCU and NUM. UASA has traditionally represented higher-graded and professional workers.

Respondents in the sample ranged in age range from 18 to 55 , with the majority aged from 25 to 45 . In total, 219 males and 80 females were included in the sample. The majority of workers surveyed had only a basic or some school education but did 
not have matric. Of the respondents, $164(54.8 \%)$ had a basic education or some schooling, $68(22.7 \%)$ had finished high school, $19(6.4 \%)$ held a diploma, $35(11.7 \%)$ had a certificate and $13(4.3 \%)$ held degrees. Some of the respondents surveyed have worked at their respective companies for over 25 years. However, the majority have worked for their companies for less than 10 years. The average job tenure was 9 years.

The majority of workers surveyed fell into the Category $B$ job band of the Paterson job grading system. Category A workers were included in the B band for purposes of wage negotiations, and consist of unskilled and low-skilled employees. Of the respondents, 13 (4.3\%) fell into Category A and 245 (81.9\%) into Category B.

Categories $A, B$ and $C$ workers are typically highly unionised, and there has been keen rivalry between NUM and AMCU to recruit these workers for membership. UASA typically represents more highly skilled workers in the $C, D$ and $F$ bands. Of the respondents, $35(11.7 \%)$ fell into category $C$ and $6(2 \%)$ into the $D$ and $F$ bands.

Some of the respondents surveyed have been members of NUM for more than 20 years. However, the majority of respondents (nearly $71 \%$ ) joined their union in the past two years. This is in line with the trends seen in Rustenburg in the last two years, where AMCU has been gaining significant traction since January 2012. The average length of union membership is 3.3 years.

Perception of socio-economic status was evaluated in accordance with the test developed by Adler, Epel, Castellazzo and Ickovics (2000). Respondents were given a drawing of a ladder with 10 rungs, numbered from 10 at the top to 1 at the bottom. They were asked to think of this ladder as representing where people stand in South Africa. At the top (10) are people who are best off, those who have the most money, most education, and the best jobs. At the bottom (1) are people who are worst off, those who have the least money, least education, and worst jobs or no job. Respondents were asked to place a cross on the rung that best represents their position on the ladder. Of the respondents, $156(52.2 \%)$ ranked themselves at the bottom (1) of the ladder, with $36(12 \%)$ ranking themselves as a 4 and 31 as a $5(10.4 \%)$. The average ranking for all respondents was 2.92 .

\section{Results and discussion}

The reliability of the results of the survey was tested using Cronbach's Alpha (see Table 1 below). Four items were excluded so that the respective constructs could achieve an acceptable Cronbach's Alpha score. Respondents were surveyed on the item Union Militancy, but their responses scored too low (0.44) to be reliable and were omitted from the results. The Cronbach's Alpha scores are shown in Table 1 below.

Table 1

Final survey Cronbach's Alphas

\begin{tabular}{|l|c|c|}
\hline \multicolumn{1}{|c|}{ Construct } & Cronbach's Alpha & Number of items \\
\hline Procedural Justice (Workplace) & 0.792 & 4 \\
\hline Procedural Justice (External) & 0.798 & 3 \\
\hline Distributive Justice (Workplace) & 0.736 & 3 \\
\hline Distributive Justice (External) & 0.837 & 4 \\
\hline Union Instrumentality & 0.784 & 4 \\
\hline Union Loyalty & 0.702 & 5 \\
\hline Intent to Participate & 0.664 & 3 \\
\hline
\end{tabular}


When the NUM and AMCU samples were compared, significant differences in their means were found - see Table 2 below.

Table 2

Descriptive statistics comparing NUM and AMCU

\begin{tabular}{|c|c|c|c|c|c|c|c|c|}
\hline 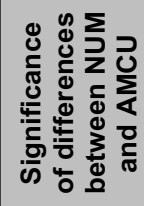 & 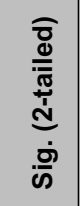 & ঃ & ঃ & ঃ & ঃ & ঃ. & 8 & ঃ \\
\hline \multirow{5}{*}{ गे } & 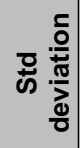 & 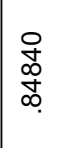 & $\begin{array}{l}\bar{్} \\
\varnothing \\
\varnothing\end{array}$ & $\begin{array}{l}\stackrel{8}{\circ} \\
\stackrel{0}{\hat{\sigma}}\end{array}$ & $\underset{\substack{+\infty}}{\stackrel{9}{+}}$ & $\begin{array}{l}\widehat{o} \\
o \\
f \\
\infty \\
0 .\end{array}$ & 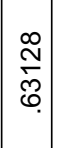 & $\begin{array}{l}\tilde{N} \\
\stackrel{0}{0}\end{array}$ \\
\hline & 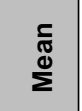 & $\frac{m}{o}$ & 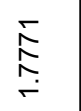 & $\begin{array}{l}0 \\
0 \\
0 \\
\\
\stackrel{2}{r}\end{array}$ & $\underset{\substack{\mathfrak{d} \\
\stackrel{\Sigma}{\sim}}}{ }$ & 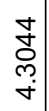 & $\mid \begin{array}{c}\hat{o} \\
\stackrel{\alpha}{\dot{\gamma}} \\
\end{array}$ & 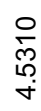 \\
\hline & $\begin{array}{l}\dot{x} \\
\sum^{\frac{\omega}{z}}\end{array}$ & $\stackrel{\stackrel{\leftrightarrow}{N}}{\underset{\sim}{*}}$ & $\underset{+}{\stackrel{\leftrightarrow}{ }}$ & $\begin{array}{l}\hat{\sigma} \\
\dot{\sigma}\end{array}$ & $\begin{array}{l}\stackrel{\leftrightarrow}{ } \\
\dot{+}\end{array}$ & $\begin{array}{l}8 \\
i \\
\end{array}$ & $\begin{array}{c}8 \\
0 \\
i \infty\end{array}$ & : \\
\hline & $\dot{\Sigma}$ & $\stackrel{\leftrightarrow}{\stackrel{\leftrightarrow}{-}}$ & 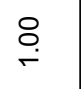 & $\stackrel{8}{\stackrel{\circ}{-}}$ & $\stackrel{\text { \& }}{-}$ & 号 & $\mid \begin{array}{l}\stackrel{q}{\mathrm{i}} \\
\text { | }\end{array}$ & $\stackrel{\hat{\sigma}}{\stackrel{r}{ }}$ \\
\hline & z & $\stackrel{\mathfrak{N}}{\stackrel{1}{*}}$ & $\stackrel{N}{\stackrel{N}{\sim}}$ & $\grave{I}$ & $\stackrel{N}{\stackrel{N}{*}}$ & $\stackrel{?}{\sim}$ & $\stackrel{\underset{N}{\sim}}{\stackrel{N}{*}}$ & $\stackrel{N}{\sim}$ \\
\hline \multirow{5}{*}{$\sum_{\mathbf{z}}^{\mathbf{z}}$} & 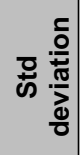 & $\stackrel{ }{\frac{0}{r}}$ & 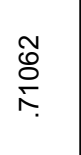 & 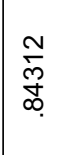 & $\begin{array}{l}0 \\
\stackrel{0}{0} \\
6\end{array}$ & $\begin{array}{l}1 \\
\infty \\
0 \\
\varnothing \\
\varnothing\end{array}$ & 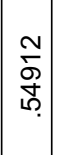 & 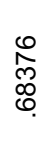 \\
\hline & $\begin{array}{l}\text { ⿷匚 } \\
\stackrel{\Xi}{\Sigma}\end{array}$ & 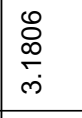 & 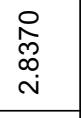 & 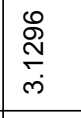 & 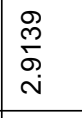 & $\begin{array}{l}\stackrel{\infty}{N} \\
\stackrel{్}{2} \\
\dot{m}\end{array}$ & \begin{tabular}{|c|} 
\\
$\stackrel{\infty}{O}$ \\
6 \\
n. \\
\end{tabular} & 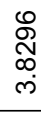 \\
\hline & 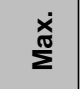 & $\stackrel{\stackrel{R}{\sim}}{\stackrel{\sim}{\sim}}$ & $\begin{array}{l}\hat{\sigma} \\
\dot{\sim}\end{array}$ & $\begin{array}{l}\hat{\theta} \\
\dot{\sigma}\end{array}$ & $\begin{array}{l}\stackrel{\leftrightarrow}{ } \\
\dot{\forall}\end{array}$ & $\begin{array}{l}\text { : } \\
\dot{b}\end{array}$ & $\mid \begin{array}{l}\dot{8} \\
\dot{+} \\
\dot{x}\end{array}$ & : \\
\hline & $\dot{\Sigma}$ & $\stackrel{\circ}{\circ}$ & 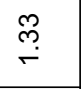 & $\stackrel{8}{\stackrel{\circ}{-}}$ & $\stackrel{\leftrightarrow}{\stackrel{\circ}{-}}$ & 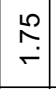 & 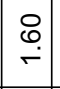 & $\stackrel{\hat{o}}{\stackrel{1}{*}}$ \\
\hline & z & ৪ & ৪ & ৪ & ৪ & ৪ & ৪) & ৪ \\
\hline & & 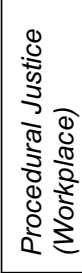 & 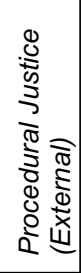 & 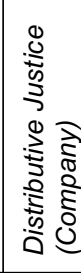 & 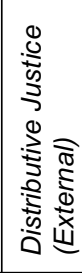 & 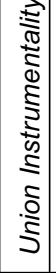 & 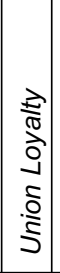 & 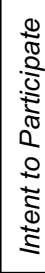 \\
\hline
\end{tabular}


T-tests were performed on the independent samples to determine whether the differences in mean were coincidental or whether they were statistically significant (i.e. belonging to the same population). There is a significant difference in the mean scores for all variables of the NUM and AMCU samples as p-values of 0.00 were recorded for all constructs. More specifically, when comparing the AMCU and NUM samples in respect of the means of the different constructs, the following observations were made: AMCU members recorded statistically significantly lower perceived levels of both Procedural and Distributive Justice (workplace and external) than members of the NUM. AMCU also scored significantly higher on Union Instrumentality than NUM. This indicates that AMCU has been more effective in mobilising individuals around perceived injustices than NUM and also means that AMCU members see their union as more effective in bringing about change where perceived injustices occur. This finding ties in with the greater intention to participate in collective union action recorded by AMCU members. For NUM to increase union participation by members, it should determine why its efficiency as a union is perceived to be lower than that of AMCU. AMCU members on average reported higher levels of loyalty to the union than NUM members. This also ties in with the greater likelihood of AMCU members participating in collective union action than that reported by NUM members. As found by Metochi (2002) and Barling et al (1992), these results show a significant positive relationship between union loyalty and willingness to strike or participate in union activities.

\section{Regression comparisons}

A simple multiple linear regression was conducted to evaluate the effects of the various constructs on intention to participate in collective action (dependent variable) for members of NUM and AMCU. This was intended to provide deeper insights into the methods used by the unions to mobilise individuals to engage in collective action. More specifically, it would be able to compare whether individuals were more likely to be driven to collective action by perceived injustices or union instrumentality. In addition, it was tested whether workplace issues were more effective than external injustices, or vice versa, in mobilising individuals towards collective action. The effect of the constructs of "procedural justice" (both workplace and external) and "distributive justice" (both workplace and external) and the constructs "union instrumentality" and "union loyalty" on the dependent variable "intention to participate in collective action", was modelled. Based on the R-squared value in Table 3 below, the model could explain only $12 \%$ of the variance in the dependent variable (intention to engage in collective action) for NUM members but $57 \%$ of variance in "intention to engage in collective action" for AMCU members.

This is further explained in Table 3 where it can be seen that union loyalty and union instrumentality make a statistically significant contribution to intention to participate in collective action for NUM members, with loyalty making the biggest contribution. However, the constructs under review only explained $12 \%$ of the variance in the dependent variable for NUM members.

In the AMCU sample, the constructs under review explained $57 \%$ of the variance in the dependent variable. For AMCU members, Union Loyalty and Procedural Justice (External) made the most significant statistical contribution to variance in the dependent variable when all variables were included in the model. 
Table 3

Comparison of multiple regression results between NUM and AMCU

\begin{tabular}{|c|c|c|}
\hline & NUM & AMCU \\
\hline \multicolumn{3}{|l|}{ Model $y$} \\
\hline $\mathrm{R}$ & 0.347 & 0.756 \\
\hline$R$-square & 0.120 & 0.572 \\
\hline Adj. R-Square & 0.057 & 0.556 \\
\hline Procedural Justice (Workplace) & -0.201 & -0.046 \\
\hline Procedural Justice (External) & -0.075 & $-0.223^{*}$ \\
\hline Distributive Justice (Company) & 0.024 & -0.013 \\
\hline Distributive Justice (External) & 0.038 & -0.055 \\
\hline Union Instrumentality & 0.2438 & 0.052 \\
\hline Union Loyalty & $0.317^{*}$ & $0.387^{*}$ \\
\hline
\end{tabular}

Unstandardised Beta's presented * $p<0.05$

The lower level of union loyalty and instrumentality from NUM members is indicative of NUM's focus on workplace matters with less emphasis on social injustice, whereas AMCU members' focus on external procedural justice is reflective of broader perceived social inequality. It must be noted that the AMCU members were almost all previously NUM members. The union itself can be the cause of grievances, and injustice stemming from union actions and the implications for membership is another area that warrants more attention (Klandermans 2004). The NUM results may also indicate a degree of union bureaucratisation. Studies on union bureaucratisation described the disconnect that arises between union leaders and their members as unions mature over time and union officials see their material conditions change significantly from those of their members (Allen 2010). In the case of full-time shop stewards, as seen in South Africa (Bernstein 2013), union officials are removed from the shop floor and do not experience the same working conditions and problems as members, so that they gradually become less patient with and understanding of complaints from members (Allen 2010). Applying the social exchange framework to unions suggests that members' satisfaction, commitment and participation are dependent on their perceptions of the extent to which the union values their contributions and cares about their well-being (Johnson \& Jarley 2004).

\section{Discussion}

The role of union leaders is to convert perceptions of individual injustice into collective action by promoting group cohesion and identity (Johnson \& Jarley 2004). The attitudes of the two unions could not be more different, even though the vast majority of AMCU members were members of NUM less than three years ago. The views of the AMCU members indicate that using external injustices is an effective way to attract members from an incumbent union. AMCU has an advantage over NUM based on its outsider status as it is not a signatory to any of the current labour agreements that would limit an incumbent union and has no agreements in place that would temper its demands. This has implications for SM theory in IR, in particular, which is based on the assumption that the target of the collective action must have a direct influence on the perceived injustice (Gahan \& Pekarek 2013; Kelly 1998)

The AMCU approach of combining injustices that go beyond workplace-related grievances and demands makes it impractical for the union to confine itself to labour relations regulations in the actions it embarks on. This means that AMCU would have to 
attract support from other social movements and NGOs to address the external injustices and retain the loyalty of its members. Alternatively, AMCU will have to refocus on workplace issues where it has a simpler task of extracting benefits for its members. This will become increasingly difficult over time. Rigg (1987) argues that high levels of participation eventually subside as most members go back to a normal routine and only a minority of members find the rewards of participation high enough to sustain their interest. However, this may last longer than Rigg anticipated in a country with the inequalities that characterise South Africa.

NUM is in a disadvantaged position in that it has historically been effective in dealing with workplace-related matters but is not able to mobilise its members for collective action around external injustices in view of its alliance with the ANC government. As long as mine workers feel that they are the victims of both workplace and external injustice, the membership of NUM will decline. This perception is enhanced by the bureaucratisation of NUM, which has taken place over time. As NUM became entrenched in the mining companies, elected shop stewards in full-time positions moved away from underground operations and into union offices, thereby alienating their leaders from rank-and-file members. This has led to smaller groups of union officials making decisions that do not always reflect the views of members, creating space for AMCU (Buhlungu \& Bezuidenhout 2008).

\section{Conclusions}

The economic and social context in the North West Province creates the opportunity for a trade union to link the social context to the workplace, and this is the primary difference between the approaches of AMCU and NUM. AMCU mobilised both on the mines and among the shack dwellers during 2012 and 2014, whereas NUM concentrated on workplace-related matters and the conclusion of a collective agreement on conditions of service. It limited its engagement on broader social issues to the Cosatu/ANC alliance (Seccombe 2012; Gordon et al 2013; Zibi 2014). By comparing members of NUM with those of AMCU, it was possible to gain insights into the mobilisation methods that are most effective in an industry such as mining in an emerging economy. It was found that union instrumentality, union loyalty, and the intent to participate in collective union action differed substantially between union members, even though they had belonged to the same union less than three years previously. This study contributes to the call for further research by Van Stekelenburg and Klandermans (2013) on the impact of the socio-political context on people's routes to protest. By looking at different constructs of unionisation and social justice theory, the study has shown the interaction between the role of factors external to the workplace, namely socio-economic conditions, and intent to participate in union activities. It is unlikely that the AMCU strategy would have succeeded in communities that do not feel as deprived as those in the platinum belt; AMCU SM methods are most successful if employees find themselves alienated from society. When unions use SM methods they inevitably draw other non-industrial relations players into the fray, such as government and NGOs. There is, however, a danger for the union that its ability to gain concessions outside the workplace is limited and concessions from employers are unlikely to change societal conditions. In the case of $\mathrm{AMCU}$, the low score for union instrumentality appears to be indicative of an understanding among its members that AMCU is a social movement rather than a workplace instrument. This has implications for efficacy-based theories that predict collective action based on the perception that the target of the collective action has the ability to influence an advantageous outcome. 
A further implication of our findings is that unions in alliances with political parties or groupings that can be blamed for external injustices make themselves vulnerable to unions such as AMCU. The South African context of a Cosatu/ANC alliance is not unique and Allen (2010) and Bai (2011) have shown that close relationships or alliances between trade unions and political parties in power have led to union leaders losing focus on servicing members' needs where they are in conflict with the political objectives. While Cosatu has a proud anti-apartheid struggle history and has played a key role in bringing about democracy in South Africa, it has found it difficult to mobilise members over issues that affect its members who live in marginalised communities and in informal settlements and rural areas (Buhlungu \& Bezuidenhout 2008).

It was shown how a trade union effectively uses SM methods to recruit and mobilise members to collective action by combining workplace and external injustices within a deprived socio-economic context. While this approach is effective in the short to medium term, it is not clear to us how this can be sustained: at some stage the union members will demand that the union engage more directly with role players capable of directly influencing the desired outcomes. The study opens further areas of research into the limitations and implications of combining workplace and external injustices.

The study has several implications for managers. The findings showed that factors external to the workplace play an important role in an employee's decision to participate in industrial action. It is clear that fair pay and good management processes are not sufficient to prevent industrial action when workers come from deprived communities. The industrial relations climate in the platinum belt has shown that protests over wages can be inflamed by issues outside the workplace. It is therefore prudent for companies operating in these contexts to do more to address socio-economic conditions affecting their employees, including forming partnerships with local authorities and improving the living conditions and education of employees wherever possible. This approach highlights the need for further research on the role of social development in the context of human resource management, with the emphasis on development rather than social responsibility or stakeholder management. Companies can expect social demands to escalate and union demands to include issues such as access to water and sanitation, electricity and transport and the narrowing of the wage gap. The lessons for companies from developed economies is that conventional HR management is insufficient in this context and social factors should be managed when attempting to build a more stable labour relations environment in emerging markets.

\section{List of references}

Adler, NE, Epel, ES, Castellazzo, G \& Ickovics, JR. 2000. Relationship of subjective and objective social status with psychological and physiological functioning: Preliminary data in healthy, white women. Health psychology 19(6):586-592.

Al Jazeera. 2012. September. Q\&A: Understanding the Marikana strikes. Available at: http://www.aljazeera.com/indepth/features/2012/09/20129994446402210.html (accessed November 2014).

Allen, K. 2010. The trade unions: From partnership to crisis. Irish Journal of Sociology 18(2):22-37.

Bai, R. 2011. The role of the All China Federation of Trade Unions: Implications for Chinese workers today. WorkingUSA 14(1):19-39. 
Barling, J, Fullagar, C, Kelloway, EK \& McElvie, L. 1992. Union loyalty and strike propensity. The Journal of Social Psychology 132(5):581-590.

Bernstein, A. 2013. Marikana and the future of South Africa's labour market. CDE Round Table 21, March, 2013.

Buhlungu, S. 2013. Farewell to Innocence! Dilemmas and turning points for Cosatu. SA Labour Bulletin 37(4):24-27.

Buhlungu, S \& Bezuidenhout, A. 2008. Union solidarity under stress. The case of the National Union of Mineworkers in South Africa. Labor Studies Journal 33(3): 262-287.

Gahan, P \& Pekarek, A. 2013. Social movement theory, collective action frames and union theory: A critique and extension. British Journal of Industrial Relations 51(4):754-776.

Giguère, B \& Lalonde, RN. 2010. Why do students strike? Direct and indirect determinants of collective action participation. Political Psychology 31(2):227-247.

Gordon, S, Roberts, B \& Struwig, J. 2013. The state of the union? Attitudes to South African trade unions. Human Science Research Council Review, March. Available at: http://www.hsrc.ac.za/en/review/hsrc-review-march-2013/the-state-of-the-union (accessed November 2014).

Gordon, S, Philpot, JW, Burt, RE, Thompson, CA \& Spiller, WE. 1980. Commitment to the union: Development of a measure and an examination of its correlates. Journal of Applied Psychology 65(4):479.

Goslinga, S \& Sverke, M. 2003. Atypical work and trade union membership: Union attitudes and union turnover among traditional vs atypically employed union members. Economic and Industrial Democracy 24(2):290-312.

Johnson, NB \& Jarley, P. 2004. Justice and union participation: An extension and test of mobilization theory. British Journal of Industrial Relations 42(3):543-562.

Kelloway, EK, Francis, L, Catano, VM \& Teed, M. 2007. Predicting protest. Basic and Applied Social Psychology 29(1):13-22.

Kelly, J. 1998. Rethinking industrial relations: Mobilization, collectivism and long waves. London and New York: Routledge.

Klandermans, B. 1997. The social psychology of protest. Oxford: Blackwell.

Klandermans, B. 2002. How group identification helps to overcome the dilemma of collective action. American Behavioral Scientist 45(5):887-900.

Klandermans, B. 2004. The demand and supply of participation: Social-psychological correlates of participation in social movements. The Blackwell companion to social movements, Malden, MA. Blackwell:360-379.

Malala, J. 2012. The Marikana action is a strike by the poor against the state and the haves. The Guardian. Available at: http://www.theguardian.com/commentisfree/ 2012/aug/17/marikana-action-strike-poor-state-haves/print (accessed October 2014).

Mathews, C. 2013. Platinum woes - Can industry survive crisis? Financial Mail, September. Available at: http://www.financialmail.co.za/fm/2012/09/06/platinum-woes--can-industry-survive-crisis (accessed October 2014).

Metochi, M. 2002. The influence of leadership and member attitudes in understanding the nature of union participation. British Journal of Industrial Relations 40(1): 87-111. 
Peyper, L. 2012. There won't be any big bang break from the ANC. Finweek. Available at: http://finweek.com/2012/09/04/there-wont-be-any-big-bang-break-from-the-anc/ (Accessed October 2014).

Rigg, P. 1987. Miners and militancy: A study of branch union leadership. Industrial Relations Journal 18(3):189-200.

Seccombe, A. 2012. Little-known miners union stirs things up. BusinessDay. Available at: http://www.bdlive.co.za/articles/2012/03/01/little-known-miners-union-stirs-things-up (accessed October 2014).

Van Stekelenburg, J \& Klandermans, B. 2013. The social psychology of protest. Current Sociology 61(5-6):886-905.

Zibi, S. 2014. Federation torn apart as it fails to heed the new politics. Business Day. Available at: http://www.bdlive.co.za/opinion/2014/02/21/federation-torn-apart-as-it-failsto-heed-the-new-politics (accessed October 2014). 